\title{
Mangrove ecosystem data inventory using unmanned aerial vehicles (UAVs) in Yogyakarta coastal area
}

N. Khakhim, Muh A. Marfai, A. Wicaksono, W. Lazuardi, Z. Isnaen, et al.

N. Khakhim, Muh A. Marfai, A. Wicaksono, W. Lazuardi, Z. Isnaen, T. Walinono, "Mangrove ecosystem data inventory using unmanned aerial vehicles (UAVs) in Yogyakarta coastal area," Proc. SPIE 11311, Sixth Geoinformation Science Symposium, 113110M (21 November 2019); doi: $10.1117 / 12.2547326$

EDIE Event: Sixth Geoinformation Science Symposium, 2019, Yogyakarta, Indonesia 


\title{
Mangrove Ecosystem Data Inventory Using Unmanned Aerial Vehicles (UAVs) in Yogyakarta Coastal Area
}

\author{
N. Khakhim, Muh A. Marfai, A. Wicaksono, W. Lazuardi, Z. Isnaen, T. Walinono \\ ${ }^{a}$ Faculty of Geography, Universitas Gadjah Mada, \\ Sekip Utara Jalan Kaliurang, Bulaksumur, Yogyakarta, 55281 \\ nurulk@ugm.ac.id
}

\begin{abstract}
Mangrove ecosystem is one of coastal resources that have many benefits for coastal communities. The mangrove ecosystem has very high economic and ecological functions if it is developed and preserved properly. Nowadays, many mangrove ecosystems are threatened by human activities. It is necessary to preserve and develop the mangrove ecosystems to avoid the impact of human activity and to increase their usefulness. In the process of developing the mangrove ecosystems, detailed data are required to provide a comprehensive overview of the environmental and physical conditions of the mangrove ecosystems. The study aims at identifying and making the inventory of the existing condition of the mangrove ecosystems related to mangrove cover and biodiversity. The data are collected using aerial photography (UAVs), field observation and measurement. The data inventory making is the first step in the process of developing and preserving the mangrove ecosystems. It finds that the use of the UAVs for the mangrove ecosystem data inventory making can give high accuracy data. The mangrove cover can easily be identified using on screen digitization analysis. The width of the mangrove in Baros coastal area is 2.59 hectares, consisting of Rhizophora, Avicennia, Bruguiera, Nypa and Acanthus, which is situated on the north part of Opak river and in the riverbank of Old Winongo river. Finally, the UAVs can be a promising technology in managing and monitoring the mangrove ecosystems.
\end{abstract}

Keywords: mangrove, data inventory making, unmanned aerial vehicles, Yogyakarta.

\section{INTRODUCTION}

Mangrove forest is tropical vegetation community consisting of various mangrove genus that can grow and develop in tidal areas of muddy coasts such as those of shallow bays, estuaries, deltas and protected coastal areas [1]. According to [2], mangrove forest has location requirement for optimal growth and characteristics as follows: 1) not influenced by climate, 2) influenced by tidal current, 3) inundating sea water, 4) low coastal land, 5) lack of crown structure, 6) the tree genus including api-api (Avicennia), pedada (Sonneratia), bakau (Rhizophora), lacing (Bruguiera), nyirih (Xylocarpus), and nipah (Nypa).

Although the mangrove forest habitat is specific because it has optimal requirements and certain environmental characteristics, but each type of mangrove has its own ecology. Such condition causes the formation of various kinds of communities so that it can be conducted by zoning. The emergence of zoning phenomenon that occurs in mangrove forests is very closely related to several factors, including the soil type, the openness of mangrove areas from the waves, salinity and tidal influences [3].

In addition to the aforementioned factors, the tidal current of sea water also influences the mangrove genus growing in certain area. Watson in [4] describes five inundation classes resulting from the correlation between the height of the tidal water inundation and the inundating period and the genus of the mangrove trees. The inundation classes are:

1. The coastal area inundated by all high tides in which the mangrove genus, Rhizophora, are found.

2. The coastal area inundated by medium high tide in which the mangrove genus, Avicennia are found.

3. The coastal area inundated by normal high tide in which the mangrove genus, Rhizophora, Ceriops and Bruguiera, are found.

4. The coastal area inundated by spring tides in which the mangrove genus, Bruguiera, are generally found, which form pure stands. However, Bruguiera are occasionally found in the areas with good drainage.

Sixth Geoinformation Science Symposium, edited by Sandy Budi Wibowo, Andi B. Rimba

Stuart Phinn, Ammar A. Aziz, Proc. of SPIE, Vol. 11311, 113110M · (c) 2019 SPIE

CCC code: 0277-786X/19/\$21 - doi: 10.1117/12.2547326

Proc. of SPIE Vol. 11311 113110M-1 
5. The coastal area inundated by exceptional or equinoctial tides in which the mangrove genus, Bruguiera, is found wellgrowing and occasionally associated with ferns, such as Acrostichum.

Mangrove plays important ecological and economic roles in supporting coastal area development. Followings are several physical usefulness and roles of the mangrove: flood control [4], coastal erosion and abrasion control [5], [6], [7] the intrusion buffer (absorption) of sea water into shore, salt-loaded storm and wind buffer [5], [6], [8], [9], decreasing atmospheric carbon dioxide $\left(\mathrm{CO}_{2}\right)$ content (air pollution) [5], [6], [7], [8], [9], tethering buffer of poisonous pollutants in coastal waters [7], [8], [9] and playing a role in island formation and stabilizing coastal area [5], [9]. Some biological usefulness and roles of mangrove forest are among others: the living place of marine biota in which the biota find their shelter, look for foods, including spawning and parenting [5], [7], [8], the food source for the genus living around the forest, and the living place of other various genus of animals [6], [8], [9] such as monkeys, crocodiles, and birds. Some economic usefulness and roles of mangrove forest are among others: recreation area and tourist object [5], [6], [7], [8], [9], the source of firewood and construction lumbers [5], [6], [7], [9], producer of sea foods such as fishes, shrimps and crabs [7], producer of herbal medicines [6] such as the leaves of Bruguiera as tumor inhibitor, as the place where the coastal people earn their livelihood as fishermen and aquaculture farmers [5], [6], [7], [8], [9].

The existence of the mangrove forest in coastal area closely relates to other ecosystems that form broader and very complex ecosystem [10]. Mangrove forest interrelates to seagrass field, barrier reefs, sand and mud flats that are adjacently situated [6]. Thus, if degradation takes place to one of the ecosystems, the degradation will have significant impact on other ecosystems. UNEP [6] categorizes the threat and the causal factors of the loss of the mangrove forest among others into conversion to agricultural land or aquaculture, the development of coastal areas, exploitation, pollution, indirect hydrological interference and change, extreme weather and climate change. The increase in population causes pressure for mangrove forest. The exploitation of mangrove forest is not only conducted to the products of the forest, but also extends to the land use of the mangrove forest. Consequently, the excessive exploitation of the mangrove forest by human beings results in the serious degradation of the forest. Followings are some causal factors of the conversion of the mangrove forest that cause environmental problems [10]:

1. The economic pressure of the people living in the surrounding areas of the mangrove forest causes excessive exploitation of the forest by felling the mangrove trees for firewood, construction lumbers and charcoal that are sold in market to fulfill the urgent needs of their family.

2. The lack of knowledge of the people of the usefulness, the roles, and the functions of mangrove forest for the surrounding waters related to marine biota.

3. The desire to massively develop aquaculture land in the hope of getting profit without any sufficient knowledge in shrimp and fish breeding.

4. The domination of economic consideration over environmental consideration.

Also, mangrove ecosystem faces serious threat, especially the degradation resulting from both natural and human factors [11]. The mangrove ecosystem in Baros coastal area is situated in the lower stream of Opak River in South Java coastal area that directly disembogues into Indian Ocean. It has been known that South Java coastal areas are potentially destroyed by tsunami disaster because there is a subduction zone that stretches in the south part of the island. Additionally, flood often take place in the lower stream of the river that damage the mangrove trees in the edge of the mangrove forest, uproots the trees and brings them along with the torrential flow to the sea. The mangrove ecosystem in Baros coastal area is also vulnerable to change resulting from very massive human activity in developing aquaculture in the surrounding areas. Therefore, it is necessary to make an inventory of mangrove ecosystem information to preserve and to develop them and also to support sustainable management and monitoring.

It is necessary to plan and to invent of the detailed information of the mangrove for future sustainable management of the mangrove ecosystem. Therefore, easy and fast method must be used in measuring the mangrove. Aerial photographic mapping with UAVs integrated to on-field identification is one of promising methods in mangrove ecosystem inventory making, mapping and monitoring. UAVs represent a new approach in mapping, monitoring, and evaluation of environmental condition [12]. The technology of the UAVs is advantageous in rapid mapping an area with automatic operation, flexible and fast data acquisition process, unrestrained by weather condition, giving high resolution results $(<10$ $\mathrm{cm}$ ), and relatively affordable [12], [13]. The UAVs represent ideal and detailed observation method of an area [12]. The data resulting from the UAVs are then combined with geographic information system (GIS) for easy data analysis. The 
use of the UAVs grows rapidly in ecosystem study [14]. Up to the present the UAVs have been used in data inventory making, including types, canopy height, biomas, and canopy structure [15]. The UAVs is preferable because of their advantage of giving very good and high temporal and spatial resolution images. Additionally, the UAVs are able to give more detail spatial information than traditional survey method [16].

The study focuses on Baros coastal area of the Special District of Yogyakarta because the area is undergoing rapid development of mangrove ecotourism. During the development of the tourist area, there has not been any monitoring activity to find out the ongoing mangrove ecosystem dynamics. The study aims at identifying and making an inventory of the existing cover condition and the genus diversity of mangrove using aerial photography, on-field measurement and observation. This research focuses on mapping mangroves vegetation with the study area around $(<5 \mathrm{ha})$, so that it is appropriate to use UAVs as primary data for mangrove mapping and identification.

\section{METHODOLOGY}

\subsection{Study Area}

The study area is situated around Opak River Lagoon that administratively belongs to Tirtohargo village of Kretek Subdistrict of Bantul district. The location is selected because there is a phenomenon of mangrove ecosystem zones and also the on-going activities of the local people in managing ecosystem. Rapid development will be shown in the study location because of the sustainable and regular management of the ecosystem. The regional development is also observable in the opening of the operation of the Southern Highway Line (JJLS) and hence it is necessary to conduct a study of natural resources, especially mangrove ecosystem using UAVs in the effort to develop tourist destination of mangrove ecosystem ecotourism.

\subsection{Data Acquisition}

Aerial photograph is an image of earth surface resulting from recording process using aircraft equipped with camera sensor that serves as data source in regional analysis. The aerial images of very high spatial resolution can be acquired from aerial photographic recording using unmanned aerial vehicles (UAVs). The use of the vehicles aims at obtaining highly detailed and real time data.

The aerial photographic recording in the study is conducted using the UAVs of the type of DJI Inspire 1 Quadcopter (4 propellers) at the flying height of about 100 meters. The vehicles are used because they are suitable to the on-field condition with the coverage area that is not too wide. The type of the UAVs is optimally used in small area with the requirement of high stability. The wind velocity in the study area situated in coastal area tends to be high and the quadcopter drone is useful in the implementation of the on-field survey because it is able to stand the high velocity wind. The aerial photographs of the Baros mangrove area in the coastal area of Tirgohargo village were recorded September 5th, 2018. The data of the aerial photographs were directly acquired by the researchers on field.

\subsection{The Designing of Flying Track and Ground Control Point (GCP)}

The flying track is planned for efficient and systematic implementation of aerial photographic survey. It includes the flying tract and ground control point (GCP) spread that can change with the real on-field condition. The recording is conducted following the plan and the designed flying track that have been prepared in pre-field stage. The flying track is planned using Drone Deploy application in smartphone. The coverage area of the flying track depends on the battery life of the drone.

The preparation of the flying track is a process of planning the flying track of aircraft in doing aerial photography. The establishment of the width and the number of the flying tracks is adjusted to the area of the study and the objective of the aerial photography. It is necessary in the adaptation to consider several aspects such as flying height, sidelap, endlap, and the number of tracks, photography duration, and the planned number of photographs. The characteristics of the flying plan in the study are summarized in Table 1 and Figure 1. 
Table 1. The flying plan of UAVs

\begin{tabular}{cc}
\hline \multicolumn{2}{c}{ The flying plan of UAVs } \\
\hline Flying height & 100 meters \\
The number of tracks & 6 \\
Sidelap & $70 \%$ \\
Endlap & $85 \%$ \\
Photography duration & $12: 31$ minutes \\
The planned number of & 223 \\
photographs & \\
\hline
\end{tabular}

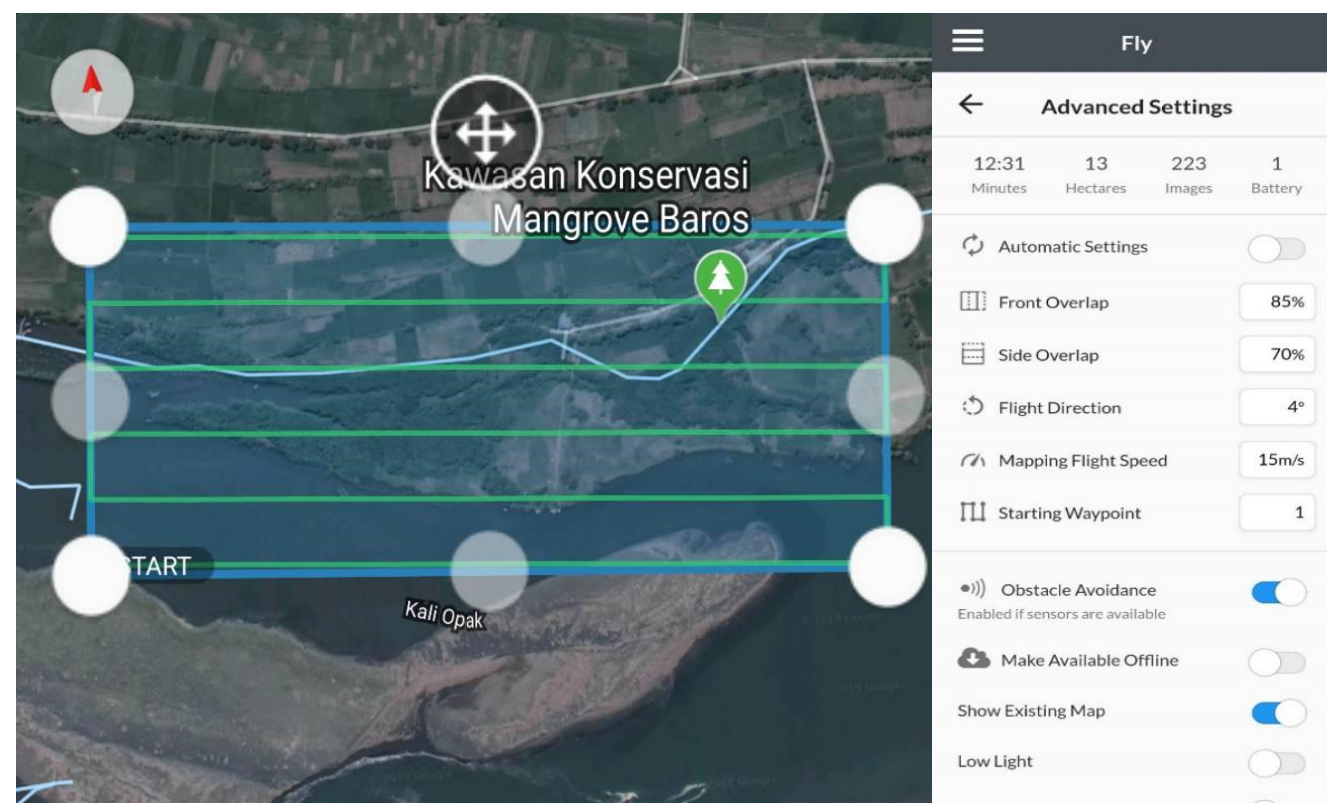

Figure 1. The flying tracks of the aerial photography survey

It is necessary to measure the coordinates of the location of the GCP and ICP points that have been distributed using high accuracy Geodetic GPS. It is because the GCP is used to acquire small format aerial photographs for accurate coordinate, while the ICP point is used to examine the accuracy level of the aerial photographs. The establishment of the coordinate has significant impact on the success of the study because the resulting accuracy values will be used in the calculation of BIG-standardized tolerance scale. It is expected that the resulting aerial photographs are of the scale standard of $1: 1,000$.

The Geodetic GPS used in the study is Navcom. The method of establishing coordinates used in the Geodetic GPS is RTK-NTRIP. The RTK-NTRIP method is able to directly acquired real time kinematic coordinate information. Subsequently, the Internet connection used in the operation is Networked Transport of RTCM via Internet Protocol (NTRIP). The method is very useful because not only the coordinates are acquired from space satellite, but also they are corrected using referential points on earth's surface. Based on some on-field measurement, the coordinates of the intended location are fixed with the standard deviation of less than 1 millimeter.

\subsection{Aerial Photograph Mosaic}

The aerial photograph mosaic is a process of combining aerial photographs into orthophoto map covering all of the portraying areas. The mosaic process in the study is carried out using Structure from Motion (SfM) of the software Agisoft PhotoScan Professional v1.3.3. The method is applied to the aerial photographs based on camera moving direction. It has 
some sequences to follow, which are photo aligning, camera optimizing, dense cloud building, mesh building, and texture building.

The photo aligning stage is useful to combine separated aerial photographs into a unit of sparse cloud points. After that, the coordinates of the combined photographs can be established using the camera optimizing feature that the real coordinates of the photographs can be established. Subsequently, cloud point is determined using the dense cloud building feature that must be in turn interpolated to establish DSM with the mesh building feature. The resulting DSM is used to prepare orthophoto using the texture building feature.

\subsection{Visual Interpretation}

The interpretation of the aerial photographs aims at obtaining the data of: the types and the distribution of mangrove vegetation, the width of the mangrove vegetation, and the tourist facility in the surrounding areas of the mangrove ecosystem. The aerial photographs are used to give detailed identified information such as the use and the cover of the surrounding land of the mangrove ecosystem.

\subsection{On-field Measurement and Observation}

The observation is conducted to give in-depth and thorough observation results and then the results are documented for further analysis of the correlation among the existing phenomena. The objectives of the on-field observation are among others: to ground-check the interpretation results of the aerial photographs, to find out the genus of the fauna in the mangrove ecosystem, and to identify the types of the management of the mangrove ecosystem that has been being organized in the location of the study.

The on-field measurement is conducted to obtain the data of the physical parameters of the environment that supports the growth of the mangrove vegetation such as soil condition, water condition and tidal current. It is conducted by drawing the sample of the soil and the water in the location of the study in which the mangrove vegetation grows and in the planned location of the development area of the mangrove vegetation. The data may also be collected from government institutions or the prior studies in the same study area.

\section{RESULTS AND DISCUSSION}

\subsection{The Aerial Photography of the Mangrove Ecosystem in Baros1 Coastal Area}

The aerial photography is conducted using DJI Inspire. The number of the resulting photographs is 234 photographs. They have been selected on their quality and their sharpness. There are 6 ground control points for geometric correction and 4 independent control points to find out horizontal and vertical accuracies. The results of the calculation of the ICP points in orthomosaic and the DSM in Baros coastal area indicate that the horizontal accuracy is $0.127 \mathrm{~m}$ (Table 2) and the vertical accuracy is $0.497 \mathrm{~m}$ (Table 3). Following BIG basic rules, the resulting aerial photographs of the mangrove ecosystem in Baros coastal area can be processed into spatial data at the scale output of 1:1,000

Table 2. The calculation of horizontal RMSE

\begin{tabular}{|c|c|c|c|c|c|c|c|c|c|}
\hline $\begin{array}{l}\text { Point } \\
\text { Nam } \\
\text { e }\end{array}$ & X (GPS) & $\begin{array}{l}\text { X (Aerial } \\
\text { Photo) }\end{array}$ & $(\mathbf{D ~ X})$ & $\begin{array}{c}(\mathrm{D} \\
\mathbf{X})^{\wedge} \mathbf{2}\end{array}$ & Y (GPS) & $\begin{array}{l}\text { Y (Aerial } \\
\text { Photo) }\end{array}$ & $\begin{array}{l}\text { (D) } \\
\text { Y) }\end{array}$ & $(D Y)^{\wedge} 2$ & $\begin{array}{c}(\mathrm{D} \mathrm{X})^{\wedge} \mathbf{2}+(\mathrm{D} \\
\mathrm{Y})^{\wedge} \mathbf{2}\end{array}$ \\
\hline & 420693.76 & 420693.70 & 0.0577 & 0.003 & 9114749.85 & 9114749.90 & 0.05 & 0.00329 & \\
\hline \multirow[t]{2}{*}{ ICP 1} & 6 & 8 & 3 & 3 & 1 & 9 & 7 & 7 & 0.00663 \\
\hline & 420763.91 & 420763.78 & 0.1317 & 0.017 & 9114732.98 & 9114733.02 & 0.03 & 0.00153 & \\
\hline \multirow[t]{2}{*}{ ICP 2} & 9 & 8 & 8 & 4 & 8 & 7 & 9 & 0 & 0.01890 \\
\hline & 420923.68 & 420923.66 & 0.0132 & 0.000 & 9114728.03 & 9114727.99 & 0.04 & 0.00200 & \\
\hline \multirow{2}{*}{ ICP 3} & 2 & 9 & 8 & 2 & 9 & 5 & 5 & 6 & 0.00218 \\
\hline & 421041.86 & 421041.87 & 0.0123 & 0.000 & 9114788.18 & 9114788.18 & 0.00 & 0.00008 & \\
\hline \multirow[t]{5}{*}{ ICP 4} & 1 & 4 & 9 & 2 & 9 & 0 & 9 & 5 & 0.00024 \\
\hline & & & & & & & & Sum & 0.0280 \\
\hline & & & & & & & & Mean & 0.0070 \\
\hline & & & & & & & & RMSE & 0.0836 \\
\hline & & & & & & & & CE 90 & 0.1269 \\
\hline
\end{tabular}


Table 3. The calculation of vertical RMSE

\begin{tabular}{|c|c|c|c|c|}
\hline Point Name & $\mathrm{Z}$ (GPS) & Z (Aerial Photo) & $(\mathrm{D} Z)$ & $(\mathrm{D} Z)^{\wedge} \mathbf{2}$ \\
\hline ICP 1 & 24.7419 & 25.0715 & 0.3296 & 0.10863616 \\
\hline ICP 2 & 24.7435 & 24.8909 & 0.1474 & 0.02172676 \\
\hline ICP 3 & 24.7490 & 24.2666 & 0.4824 & 0.23270976 \\
\hline \multirow[t]{5}{*}{ ICP 4} & 24.7565 & 24.7352 & 0.0213 & 0.00045369 \\
\hline & & \multicolumn{2}{|r|}{ Sum } & 0.36352637 \\
\hline & & \multicolumn{2}{|r|}{ Mean } & 0.090881592 \\
\hline & & \multicolumn{2}{|r|}{ RMSE } & 0.30146574 \\
\hline & & \multicolumn{2}{|r|}{ LE 90} & 0.497388325 \\
\hline
\end{tabular}
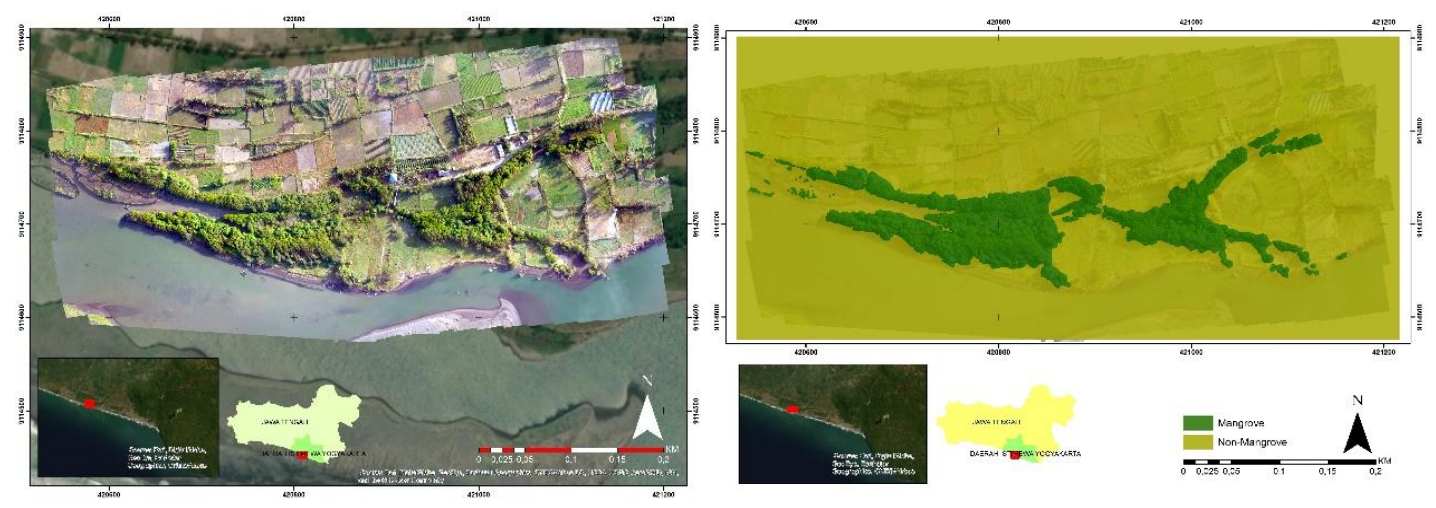

Figure 2. The aerial photograph mosaic of Baros mangrove conservation area

The resulting aerial photographs are then interpreted manually to classify mangrove objects and non-mangrove objects. It is because the study focuses on the mangrove so that it is not necessary to pay attention to other objects. The aerial photographs may be seen in Figure 2. The identification results show that the aerial photographs can be used to differentiate the mangrove objects from non-mangrove objects very well. The calculation of the aerial photographs gives the width of the mangrove ecosystem cover in Baros coastal area, which is 2.59 hectares.

The problems during the acquisition of the mangrove data with aerial photography related to the weather in the location of the study. The uncertain weather condition results in the failure to fly the unmanned aerial vehicles because of the high velocity wind. Following the existing standard operational procedure of the unmanned aerial vehicles, the vehicles should be operated in safe manner and when the wind velocity is too high, the flying operation should be canceled. The problems related to the weather, especially the high velocity wind is essentially difficult to overcome. It is because the entire location of the study is situated in coastal area with high velocity wind. Therefore, the aerial photography is conducted in the morning because the lowest velocity of the wind takes place in the morning. However, in several survey occasions the wind velocity is constantly high since morning.

\subsection{The Condition of the Mangrove in Baros Coastal Area}

The mangrove ecosystem in Baros coastal area is well-maintained and the mangrove trees grow very well. The mangrove forest in the coastal area has huge potential for tourist destination in an ecotourism. The location of the area that is not too far from the city center of the Special District of Yogyakarta and its environment condition are the reasons why the study focuses on the location. It is more likely to focus on the development of the mangrove area of Baros coastal area as educational tourism and as the center of the activity of mangrove development in the Special District of Yogyakarta. Therefore, it is expected that there will be significant improvement in the maintenance and the development of the mangrove ecosystem. 
The condition of the mangrove ecosystem in Baros coastal area is checked by considering several physical actual conditions of the ecosystem, including cover and genus identification. The identification of the mangrove condition is also conducted using literature study of prior studies. The resulting data are used as secondary data and compared to the onfield factual condition. Several prior referential studies as secondary data sources include the ones conducted by [17], [18], [19]. The mangrove vegetation in Baros coastal area is the result of cultivation that the distribution does not fit the natural mangrove zoning. Though the mangrove is the results of cultivation, there have been several mangrove vegetations that grow naturally and are able to adapt to the existing physical environment. In general, the results of the identification of the physical characteristics in the field are similar to the secondary data resulting from the literature study.

The results of the factual on-field identification of the mangrove genus are consistent with the data of the mangrove genus in the prior studies. The results of the on-field observation show that the mangrove ecosystem in Baros coastal area has two types, which are fringe mangrove and riverine mangrove. The fringe mangrove is situated north of Opak river, while the riverine mangrove is situated in the riverbank of old Winongo river. The mangrove vegetation in the fringe mangrove is dominated by the genus Rhizophora in addition to another genus such as Avicennia. The mangrove vegetation in the area is a result of new cultivation that it is still less than 2 meters of height. The other mangrove genus in the area include Rhizophora (1.46 ha), Avicennia (1.24 ha), Bruguiera (0.03 ha), and Nypa (0.02 ha) that have grown to 5 meters of height. The genus Acanthus is found growing in the riverine mangrove vegetation in smaller area. The map of mangrove genus is made by manual interpretation of the aerial photographs that are adjusted to on-field observation data. The mangroves classified into four genus have been described before. This map has not been tested for quantitative accuracy because the mapping process involves a field survey so that the map is considered to be in accordance with the conditions on the ground. The mangrove genus map may be seen in Figure 3.

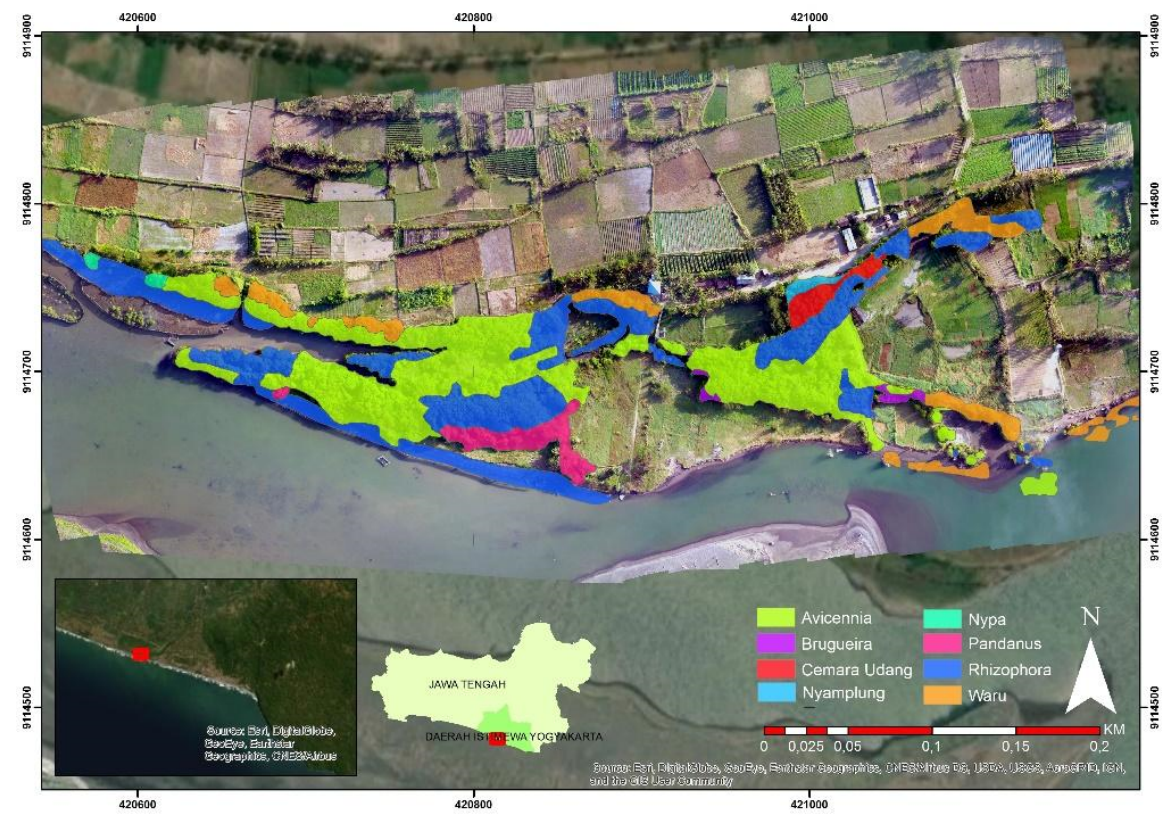

Figure 3. The mangrove genus map of Baros coastal area

There are many aspects to consider in the identification of the mangrove genus. The aspects include the association of each of the genus with the existing environmental physical condition, the textural characteristics of the aerial photographs, the heterogeneity level of the colony of each of the mangrove genus, and the results of on-field observation. Each of the aspects is analyzed and correlated to each other to give the mangrove genus map. The detailed spatial information of the mangrove ecosystem, especially the genus is ecologically and economically very important in supporting mangrove conservation and management in certain location. The main challenge in using the UAVs to identify and to make an inventory of the mangrove ecosystem is the flying height to make aerial photography. The flying height closely relates to spatial resolution magnitude and the ability of the aerial photography in extracting information. If the flying height is low, the resulting resolution is very detail, but the width of the coverage area is very small so that only little information is acquired. If the flying height is too high, the coverage area is very wide, but the resolution of the photographs decreases and it influences the possibility to identify necessary information. It is necessary to explore the 
flying height of the UAVs that ideal results are obtained, which are optimal spatial resolution to identify and to make an inventory of the characteristics of the mangrove ecosystem. Therefore, it is expected that the future use of the UAVs will continuously develop and progress significantly for the purpose of studies, the monitoring of the development of and the change in the mangrove ecosystem in Indonesia.

Considering the low awareness of the local people of the usefulness, the role and the function of the mangrove forest that causes environment degradation, it is necessary to conduct further study of the inventory making of the mangrove ecosystem condition to overcome the problem of the lack of data, the knowledge of the people and the decision makers. Some actions to make are among others to estimate the existing mangrove resource, to valuate the service of the mangrove ecosystem, to study the effectiveness of the management of the mangrove ecosystem, to understand the correlation between the mangrove ecosystem and human beings using social-economic approach, to study the adaptation of the mangrove to climate change, and to make use of long distance imaging data for mangrove study.

Considering with the objectives of sustainable development, restoring the damaged mangrove condition will help meet some of the objectives of the sustainable development. As described in the introduction if the mangrove ecosystem can be well-maintained, several objectives of sustainable development can be met [20], such as increasing the income of local people by selling mangrove processed products (The Development Objective Number 1: No Poverty), the use of the mangrove processed products for foods (The Development Objective Number 2: Zero Hunger), the development of mangrove ecotourism that is able to improve the economy of the local people (The Development Objective Number 8: Decent Work and Economic Growth), the use of the stem and the root of mangrove for industry and for environment friendly infrastructure construction materials (The Development Objective Number 9: Industry, Innovation and Infrastructure), building strong coastal communities (The Development Objective Number 11: Sustainable Cities and Communities), improving the endurance and the adaptive capacity to climate-related disasters through carbon absorption, the protection against storm, abrasion and high tide of sea water (The Development Objective Number 13: Climate Action), improving ecosystem habitat and fish spawning place (The Development Objective Number 14: Life Below Water), and reducing natural habitat degradation and protecting and preventing the extinction of the genus in danger (The Development Objective Number 15: Life on Land).

\section{CONCLUSION}

The study uses UAVs as an instrument in acquiring aerial photographic data to make an inventory of the information of the existing mangrove ecosystem integrated to on-field observation. It is necessary to pay a good attention to natural factors and other factors in analyzing the aerial photograph survey. The natural factors include wind direction and weather condition. Meanwhile, other factors include the safe flying area for drone following the existing civil aviation rules that are put in effect by government.

The results show that the integration of UAVs and the on-field observation is useful in acquiring the information of the existing mangrove ecosystem related to its cover width and its genus. The width of the mangrove in Baros coastal area is 2.59 hectares. The mangrove genus that are found in the field and can be spatialized are Rhizophora, Avicennia, Brugueira, Nypa and Acanthus. The identification results and the analysis of the condition of the existing mangrove ecosystem in Baros coastal area show that the area is very potential to rapidly develop into ecotourism and education tourism because it is supported by good infrastructure for easy access. Additionally, the surrounding areas of the riverbank of Progo River are also very potential for mangrove ecosystem development, but it is necessary to plan and to give special treatment in preserving the existing environmental condition and to support the growth and the development of the mangrove ecosystem. Therefore, the future use of the UAVs can result in significant development in the study of the mangrove ecosystem and in the monitoring of the development of and the change in the mangrove ecosystem.

\section{ACKNOWLEDGEMENT}

We would like to express our gratitude to the Ministry of Research, Technology and Higher Education for fully funding the study through Superior Higher Education Basic Research (Penelitian Dasar Unggulan Perguruan Tinggi/PDUPT). 


\section{REFERENCES}

[1] Bengen, D. G., [Sinopsis Ekosistem dan Sumberdaya Alam Pesisir. Bogor: Pusat Kajian Sumberdaya Pesisir dan Lautan], Institut Pertanian Bogor, Bogor (2000).

[2] Soerianegara., [Hutan Mangrove: Definisi dan Fungsi Hutan Mangrove di Indonesia], LIPI-Yayasan LPP Mangrove, Jakarta (1990).

[3] Pamudji., "Upaya Pengelolaan Hutan Mangrove Dilihat dari Aspek Perlindungan Lingkungan," Oseana, XXV (3), 18 (2000).

[4] Kartawinata, K., Adisoemarto, S. Soemodihardjo, S., dan Tantra, I.G.M., "Status Pengetahuan Hutan Bakau di Indonesia," Pros. Sem. Ekos. Hutan Mangrove, 21-39 (1979).

[5] Baan, C., [The Economic Valuation of mangroves: A Manual for Researchers], International Development Research Centre, Ottawa, (1997).

[6] UNEP., [The Importance of Mangroves to People: A Call to Action], van Bochove, J., Sullivan, E., Nakamura, T. (Eds), United Nations Environment Programme World Conservation Monitoring Centre, Cambridge (2014).

[7] Akanni, A., Onwuteaka, J., Uwagbae, M., Mulwa, R., and Elegbede, I.O., "Chapter 25 - The Value of Mangrove Ecosystem Services in the Niger Delta Region of Nigeria," The Political Ecology of Oil and Gas Activities in the Nigerian Aquatic Ecosystem, 387 - 437 (2018).

[8] Salem M.E., and Mercer, D.E., "The Economic Value of Mangroves: A Meta-Analysis,” Sustainability 4, 359-383 (2012).

[9] Primavera, J.H., Friess, D.A., Van Lavieren, H., and Lee, S.Y., "Chapter 1 - The Mangrove Ecosystem," World Seas: An Environmental Evaluation (Second Edition), Volume III: Ecological Issues and Environmental Impacts, 1-34 (2019).

[10] Pamudji., "Ekosistem Hutan Mangrove dan Peranannya sebagai Habitat Berbagai Fauna Aquatik," Oseano, XXVI (4), 13-23 (2001).

[11] Dahdouh-Guebas, F., Jayatissa, L.P., Di Nitto, D., Bosire, J.O., Seen, D.I., Koedam, N, "How effective were mangrove as a defence against the recent tsunami," Current Biology 15, 443-447 (2005).

[12] Messinger, M., Silman, M., "Unmanned aerial vehicles for the assessment and monitoring of environmental contamination: An example from coal ash spills," Environmental Pollution 218, 889-894 (2016).

[13] Lu, B., He, Y., "Species classification using Unmanned Aerial Vehicle (UAV)-acquired high spatial resolution imagery in a heterogeneous grassland," ISPRS Journal of Photogrammetry and Remote Sensing 128, 73-85 (2017).

[14] Pajares, G., "Overview and current status of remote sensing applications based on unmanned aerial vehicles (UAV)," Photogrammetry Engineering Remote Sensing 81, 281-329 (2015).

[15] Suwargana, N., "Analisis perubahan hutan mangrove menggunakan data penginderaan jauh di pantai Bahagia, Muara Gembong, Bekasi," Jurnal Penginderaan Jauh 5, 64-74 (2008).

[16] Messinger, M., Gregory, P., Asner, G.P., Silman, M., "Rapid Assessment of amazon forest structure and biomass using small unmanned aerial systems," Remote Sensing 8, 615 (2016).

[17] Walinono, Taufik., [Perencanaan Pengembangan Ekosistem Mangrove untuk Ekowisata di Wilayah Pesisir Daerah Istimewa Yogyakarta], Universitas Gadjah Mada, Yogyakarta (2017).

[18] Sawitri, Rani., [Strategi Pengelolaan Lingkungan Pada Ekosistem Mangrove Di Sekitar Muara Sungai Bogowonto Kabupaten Kulon Progo], Universitas Gadjah Mada, Yogyakarta (2012).

[19] Tanjung, Riski., [Kajian Fisik Wilayah Pesisir Kulon Progo untuk Penentuan Zona Kawasan Mangrove dan Tambak Udang], Universitas Gadjah Mada, Yogyakarta (2016).

[20] Blum, J., and Herr, D, "Can restoring mangroves help achieve the Sustainable Development Goals?," IUCN, 16 March 2017, https://www.iucn.org/news/forests/201703/can-restoring-mangroves-help-achieve-sustainabledevelopment-goals (1 July 2019). 